\title{
COVID-19 Pandemic and Law No. 6 Year 2018 regarding Health Quarantine
}

\author{
* Gunawan Widjaja
}

*Dean Faculty of Law Universitas 17 Agustus 1945 Jakarta, Kampus UTA’45 Sunter Agung Jakarta 14350, Indonesia

Email :widjaja_gunawan@yahoo.com

\begin{abstract}
By late March, to anticipate the spreading of COVID-19 pandemic, the President of the Republic of Indonesia has issued several regulations. The Author has examined that the main laws that were used as the based for the issuance of those regulations are Law No.6 Year 2018 regarding Health Quarantine (the Health Quarantine Law). Therefore in order to handle COVID-19 pandemic, an understanding of the Law become a must. The aim of this research is to elaborate and explain the Health Quarantine Law to reduce the COVID-19 pandemic. This research is normative legal research. The research used secondary data, which consisted of primary legal sources and secondary legal sources. Data were collected through the "google scholar machine". Data obtained were analyzed using a qualitative approach. Findings and analysis proved that besides those newly issued regulations there were several measures and acts that should be taken to handle the COVID-19 pandemic in Indonesia. The Author suggests that the Central Government shall take the necessary steps as soon as possible.
\end{abstract}

Keywords: Quarantine, COVID-19, Health Quarantine Officer, Health Quarantine

\section{INTRODUCTION}

On $31^{\text {st }}$ March 2020, President of the Republic of Indonesia issued three regulations in relation to the effort to reduce the spreading of Corona Virus Disease 2019 (COVID-19). They are:

1. President Decree No.11 Year 2020 regarding the Determination of Public Health Emergency Corona Virus Disease (COVID-19) (PD Public Health Emergency) (PRI, 2020)

2. Government Regulation No.21 Year 2020 regarding Large Scale Social Distancing in order to Accelerate the Handling of Corona Virus Disease 2019 (COVID-19) (GR Social Distancing) (GRI, 2020);

3. Government Regulation in lieu of Law No.1 Year 2020 regarding State Financial Policy and Financial System Stability to Handle Corona Virus Disease (COVID-19) Pandemic and/ or in order to Face Threat that Endangers National Economics and/ or Financial System Stability (RI, 2020).

Those regulations were further followed by the issuance of Minister of Health Regulation No.9 Year 2020 regarding Guidance for Large Scale Social Distancing in order to Accelerate the Handling of Corona Virus Disease (COVID-19) (MoH Guidance) (MoHRIR, 2020). Based on the MoH Guidance, the Minister of Health has issued several decrees that allowed Local
Government to issue a regulation with respect to the implementation of Large Scale Social Distancing. There are among others are Minister of Health Decree No.HK.01.07/Menkes/239/2020 regarding the Determination of Large Scale Social Distancing in DKI Jakarta Province Area in order to Accelerate the Handling of Corona Virus Disease 2019 (COVID-19) (MoHDKI Social Distancing) (MoHRID, 2020). The Minister of Health Decree resulted in the issuance of DKI Jakarta Governor Regulation No.33 Year 2020 regarding Implementation of Large Scale Social Distancing in order to Handle Corona Virus Disease 2019 (COVID-19) in DKI Jakarta Province (DKIGR Social Distancing) (DKIGR, 2020) and DKI Jakarta Governor Decree No.380 Year 2020 regarding Enactment of the Implementation Large Scale Social Distancing in order to Handle Corona Virus Disease 2019 (COVID-19) (DKIGD Social Distancing) (DKIGD, 2020) which are applicable for DKI Jakarta Region only. There will be many more decrees issued by the Minister of Health dan local government's regulations and decrees to implement the large scale social distancing program.

Author (Widjaja, 2020a) argued that though the GR Social Distancing referred to three laws for its existence, GR Social Distancing was actually made based on Law No.6 Year 2018 regarding Health Quarantine (Health Quarantine Law) (RI, 2018). The other two laws are Law No.4 Year 1984 regarding Infectious Disease Epidemic (Infectious Disease Law) 
(RI, 1984), and Law No.24 Year 2007 regarding Disaster Management (Disaster Management Law) (RI, 2007). Further Article 5 paragraph (1) GR Social Distancing also clearly stated that whenever Large Scale Social Distancing in a certain area of Local Government has been declared by the Minister of Health, then the relevant Local Government must implement the Large Scale Social Distancing Health Quarantine Law in accordance with Health Quarantine Law. Therefore understanding the Health Quarantine Law becomes important.

The objective of this research in to elaborate and explain the legal concept of Health Quarantine Law in order that the containment effort to handle the spreading of COVID-19 can be effective and efficient.

\section{METHODS}

Data used in this research are of secondary data, which can be freely obtained from public networks. The secondary data consisted of primary legal sources, secondary legal sources, and other sources that were ready to be used. Primary legal sources consisted of Indonesian laws and legislations and other regulations issued by governmental authorities from different countries. Secondary legal sources are information collected from textbooks, journals, and other writings from legal scholars which were made to explain primary legal sources. Other data included data that were not part of legal documents. These data shall consist of books, articles in journal dan other kinds of media, including unpublished researches and papers which related to and explained the concept of quarantine and/ or social distancing during epidemic or pandemic situations.

Data were obtained through "google machine". The collected data were first analyzed using content analysis to find the most related data for further analysis. The reduced data were then analyzed qualitatively by using a normative and comparative approach. A normative approach was conducted because part of the analysis was related to the implementation of applicable laws enforced in Indonesia. A comparative approach used to explain the concept and implementation of health quarantine and social distancing in several jurisdictions. Qualitative analysis was used because the research does not rely on the quantity of the data but to the inside knowledge and understanding of the researcher of the laws and regulations. During the analysis, the collected data from different jurisdictions were compared to find the most relevant concept and meaning that can be used to explain the aim of the research. Data triangulation was conducted to obtain a valid and reliable result. Data triangulation was conducted during content analysis.

\section{RESULTS AND DISSCUSION}

\section{Theoretical Framework}

The author finds out that there were many prior kinds of researches that discussed pandemic issues and the way to mitigate the risk of a pandemic, including the COVID-19 pandemic. There is no official definition of pandemic (Qiu, et.al., 2016-2017) (Morens, e.al., 2009). Even in the World Health Organization (WHO) guidelines, there is no definition of a pandemic. It only refers to pandemic influenza which is different from the pandemic itself (WHO, 2010) (Doshi, 2011). History showed that besides influenza, there were many other pandemics that happened prior to COIVD-19. They were ebola in 2013, HIV? AIDS in 2005 and 2012, malaria in 2015, tuberculosis in 2014 (Independent Commission on Multilateralism, 2017). Besides, there is also cholera which took 4 periods from 1817 until 1923 (LePan, 2020). However, there are several features that can be used to determine whether a plague has become pandemic. The features are: "wide geographic extension, disease movement, high attack rates and explosiveness, minimal population immunity, novelty, infectiousness, contagiousness, and severity (Morens, et.al., 2009) (Qiu, et.al., 2016-2017).

Quarantine was used to prevent the spread of the plague since 1377. Ever since it was used until the 2009 influenza $\mathrm{A}(\mathrm{H} 1 \mathrm{~N} 1) \mathrm{pdm} 09$ pandemic (Tognotti, 2013). Ever since 2009, besides quarantine and isolation, social distancing measures were used for pandemic influenza since initial action to reduce the spreading of the disease (Rashid et.al., 2014) (New Zealand Ministry of Health, 2008) (Lai and Tan, 2012). Under current publication, in relation to handling COVID-19 pandemic, quarantine, isolation and social distancing were recommended to mitigate the spreading of the disease (Wilder-Smith and Freedman, 2020) (Mahtani, et,al., 2020) (Chang et.al., 2020) (Social Science in Humanitarian Action, 2020). The efforts of voluntary isolation, quarantine, and social distancing will not provide many results to reduce the spread of pandemic (Anderson et.al., 2020). Therefore some legal measures must be made in order to make people obey. However some considerations must be made (WHO, 2005) (Richards et.al., 2006), (Blendon et.al., 2014) (Kapp, 2019) (Parmet and Sinha, 2020).

\section{Understanding Health Quarantine Law}

The Republic of Indonesia in 2018 has issued the Health Quarantine Law. The existence of the Law shall and can be used to monitor, assist, and provide sufficient enough legal ground to handle the spreading of COVID-19 in Indonesia. Based on the Law, health quarantine was defined as the efforts to prevent and ward out and in disease and/ or public health risk factors which potentially can give rise to a public health emergency. Meanwhile public health emergency was an 
extraordinary public health event which was remarked by the spreading of infectious disease and/ or event caused by nuclear radiation, biological pollution, chemical contamination, dan food born illness which potentially spread across region or nation. It is the obligation of the Central Government to determine and revoke the public health emergency situation. The procedure on how to determine and revoke the public health emergency must be regulated further by Government Regulation. As a note, PD Public Health Emergency was declared without the required Government Regulation. Prior to the determination of a public health emergency, the Central Government must declare the kind of disease and risk factor that can cause public health emergencies. At the same time or after the declaration of the public health emergency, the Central Government must also determine the Entrance point and/or national region that was infected by a public health emergency. Once the public health emergency has been declared, the Central Government must implement health quarantine quickly and precisely based on the magnitude of the threat, effectiveness, resources' support, and operational technique in consideration of state sovereignty, security, economic and social.

Health quarantine that will be conducted in the Entrance point will be conducted at the port, airport, and state land border crossing. It shall include activities of disease observation and assessment to the public health risk factor of transportation vehicle, person and goods, quarantine, isolation, vaccination, decontamination, large scale social distancing, disinfection, decontamination, etc., which shall be regulated further by Minister of Health Regulation. The implementation of the process of health quarantine in the Entrance point must be conducted by Health Quarantine Officers, which are government employees working in health sectors authorized by the Ministry of Health.

Besides at the Entrance point, health quarantine will also be conducted at the suspected place of the infectious disease and/ or exposed to the public health risk factor that can cause public health emergencies. The place or area where the health quarantines were conducted can be home, certain region/ area, and hospital. The implementation of home quarantine, area quarantine, hospital quarantine, or large scale social distancing will be conducted by Health Quarantine Officers. During home quarantine, area quarantine, hospital quarantine it is clear that the basic life needs of the person in quarantine become the responsibility of the Central Government. In view of hospital quarantine, since there were local government hospitals, the basic need of the people that were quarantine in the local governments' hospital may become the responsibility of local government. The Health Quarantine Law keeps silent on the status of large scale social distancing. However, this does not mean Central Government may keep silent that it will not be responsible because, under large scale social distancing, people in the population may still do some activities, even to work from home. The responsibility is already clear in Article 8 of Health Quarantine Law that every person shall have the right of healthcare service and daily life need during health quarantine, which, by definition, include large scale social distancing. The remaining issue is how the responsibility be divided between Central Government and Local Government, either the Provincial Government or Municipal Government.

Home quarantine is defined as the limitation of a person living in a house including the contents which were suspected to be infected by a disease and/ or contaminated in order to prevent the possibility of the spreading of the disease and contamination. Hospital quarantine is the limitation of a person in a hospital who was suspected to be infected by a disease and/ or contaminated in order to prevent the possibility of the spreading of the disease and contamination. Area quarantine is the limitation of a population in a certain area including Entrance point including its contents, which were suspected to be infected by a disease and/ or contaminated in order to prevent the possibility of the spreading of the disease and contamination. Meanwhile large scale social distancing means a limitation of activities of certain population in an area which were suspected to be infected by a disease and/ or contaminated in order to prevent the possibility of the spreading of the disease and contamination. Large scale social distancing will include at least school and workplace holiday, limitation of religious activities, and/ or limitation of activities in public area or facilities.

As ordered by Health Quarantine Law, the criteria and implementation of home quarantine, area quarantine, hospital quarantine and large scale social distancing will be regulated further in Government Regulation. The state of area quarantine and large scale social distancing will be determined by Minister of Health. The MoHDKI Social Distancing and other similar Minister of Health Decree on Local Governments were meant to be the decree. However, there were a lot of miss-regulations in form of Government Regulation that shall be used as the basis for the issuance of such as MoHDKI Social Distancing.

\section{Discussion on Health Quarantine Law}

There was no mention of "Pandemic" in Health Quarantine Law. This meant that irrespective of the situation, whether it was named pandemic, epidemic, or even plague, as long as the condition of the disease fulfills the definition of emergency public health, there will be a reason for the Central Government to declare Emergency Public Health. Upon the declaration, health quarantine can or even shall be conducted. However to 
support the current facts and conditions, for the implementation of the Health Quarantine Law, there was a lack of five or one government regulations that will regulate five things as ordered by the law. they are provisions of:

1. Determination and revocation of a public health emergency at the Entrance point and national area that was infected by public health emergency as required by Article 10 paragraph (3) Health Quarantine Law;

2. Implementation of Health Quarantine in quickly and precisely manner based on the magnitude of the threat, effectiveness, resources' support, and operational technique in consideration of state sovereignty, security, economic and social based on Article 11 paragraph (3) Health Quarantine Law;

3. The implementation procedure of area quarantine in Entrance point as instructed in Article 14 paragraph (2) Health Quarantine Law;

4. Administrative Sanction in accordance with Article 48 paragraph (5) Health Quarantine Law;

5. Criteria and implementation of home quarantine, area quarantine hospital quarantine, and large scale social distancing as regulated in Article 60 Health Quarantine Law.

The introduction of GR Social Distancing only without comprehensive regulations on other kinds of health quarantine will not be effective. As quoted in above in Theoretical Framework, to be effective, health quarantine must be conducted holistically, including isolation. The existence of the Government Regulations is not for the purpose of handling the COVID-19 Pandemic or other kinds of the pandemic, but for all kinds of situations and conditions that:

a. there was an extraordinary public health event;

b. the event was:

1) remarked by the spreading of infectious disease and/ or;

2) any event caused by nuclear radiation, biological pollution, chemical contamination, dan food born illness;

c. the event potentially spread across regions or nations.

The author insists that the Government shall issue such regulations, as they may be needed in the future. This was actually in-line with other jurisdictions that health quarantine measures can be conducted not only in pandemic situations but in all kinds of situations where public health emergency required.

In the Health Quarantine Law and its elucidation, Health Quarantine Officers were mentioned 55 times. According to the law, Health Quarantine Officers were the officials that were given authorities by the las (through the Minister of Health) to enforce the implementation of Health Quarantine Law, by way of conducting health quarantine measures, either in Entrance point or in a certain area as defined by the law. Until today there was no Health Quarantine Officer ever been appointed. Considering the importance of Health Quarantine Officers as well as now and in the future, Minister of Health shall have considered the recruitment of Health Quarantine Officers. The author seeks that in view of the public health emergency, public health graduated and postgraduated can be recruited to fill in the positions. Public health competency test shall not be held for an uncertain period from 2019. It is the obligation of the Minister of health to ensure that public health graduated and post-graduated have the required competencies. This view also dismisses the view that the only bachelor in public health degree can follow and past the public health competency test, event people with a master, doctor, and post-doctoral can conduct a similar competency test. This is because public health is a complex knowledge of health. Under the current "emergency" situation, temporary and partial recruitment can be conducted, because the Health Quarantine Officers were the only authorized personnel to enforce the implementation of the law. Otherwise, that would be chaos, because no-other authorities can enforce the law (Widjaja, 2020b).

Health Quarantine Law allowed the Health Quarantine Officer to work together with the Indonesian Police (Kepolisian Republik Indonesia) and required their assistance and cooperation. In such, the Minister of Health shall make and sign Memorandum of Understanding with the Head of Indonesian Police to regulate how they will cooperate and handle the enforcement and implementation of the law. The Health Quarantine Law also open the possibility for Local Government to involve in the action of health quarantine, which makes it possible for Minister of Health and Head of Indonesian Police to also cooperate with local government police (Satpol PP) to delegate and/ or distribute the authorization for the implementation of the law, according to their competency based on the other prevailing laws, especially with respect to Law No.23 Year 2014 regarding Local Government (Local Government Law) (RI, 2014).

Finally, the author would like to attract the attention that the author finds Minister of Health Decree No.300/MENKES/SK/IV/2009 regarding Guidance for the Influenza Pandemic Epicenter Countermeasures (MoHD Influenza Pandemic) (MoHRID, 2009). The decree was quite comprehensive, but as mentioned in the title, it was made for the purpose of the influenza pandemic. Without any means to compare with current references to laws and regulations, the reference for the existence of the decree was made in a solid manner with clear reference. 


\section{CONCLUSIONS}

Health Quarantine Law regulates things that must be done under a public health emergency. To support the enforcement and implementation of the law, at least there were five matters that need to be regulated further by way of Government Regulation(s). until today none of the Government Regulations was issued. The issuance of Government Regulation No.21 Year 2020 regarding Large Scale Social Distancing in order to Accelerate the Handling of Corona Virus Disease was not sufficient enough.

Besides, there were Health Quarantine Officers who were the only authorized personnel to enforce the law was not in existence yet. Further cooperation for the enforcement of the law at the local government level needs delegation from the central government, which will be conducted further by the Minister of Health. Such cooperation was not in existence yet. The issuance of several regulations and decrees has not yet formed solid regulations.

\section{RECOMMENDATIONS}

The Author recommends that the required Government Regulations be issued, not only for the current COVID-19 pandemic issue but for further events that might happen in the future. The Author as academician dan professional believes that universities and professionals' organization is willing to support. The Author also encourage to empower public health graduates and post-graduates to practice and implement their expertise in handling public health emergency. However, it must be supported by sufficient legal authorization as "temporary" Health Quarantine Officers. The permanent Health Quarantine Officer must be recruited from time to time. It is time to re-open the suspension for the public health competency test.

\section{REFERENCES}

1. Anderson, Roy M., Hans Heesterbeek, Don Klinkengerg and $\mathrm{T}$ Déirdre Hollingsworth. (2020). "How will country-based mitigation measures influence the course of the COVID-19 epidemic?". The Lancet;395:931-934 DOI:10.1016/S0140-6736(20)30567-5 available from

https:/www.thelancet.com/pdfs/journals/lancet/PI IS0140-6736(20)30567-5.pdf accessed on 15 April 2020.

2. Blendon, Robert \& Desroches, Catherine \& Cetron, Martin \& Benson, John \& Meinhardt, Theodore \& Pollard, William. (2006). Attitudes
Toward The Use Of Quarantine In A Public Health Emergency In Four Countries. Health affairs (Project Hope). 25. w15-25. 10.1377/hlthaff.25.w15.

3. Chang, Sheryl \& Harding, Nathan \& Zachreson, Cameron \& Cliff, Oliver \& Prokopenko, Mikhail. (2020). Modelling transmission and control of the COVID-19 pandemic in Australia.

4. Doshi, Peter. (2011). "The elusive definition of pandemic influenza." Bulletin World Health Organization, 89:532-538

DOI:10.2471/BLT.11.086173.

5. Government of Republic of Indonesia. (2020). Government Regulation No.21 Year 2020 regarding Large Scale Social Distancing in order to Accelerate the Handling of Corona Virus Disease 2019. State Gazette Year 2020 No.91, Supplement No.6487.

6. Government of the Republic of Indonesia. (2020). Government Regulation in lieu of Law No.1 Year 2020 regarding State Financial Policy and Financial System Stability to Handle Corona Virus Disease (COVID-19) Pandemic and/ or in order to Face Threat that Endanger National Economics and/ or Financial System Stability. State Gazette Year 2020 No.87, Supplement No.6485.

7. Governor of DKI Jakarta. (2020). DKI Jakarta Governor Decree No.380 Year 2020 regarding Enactment of the Implementation Large Scale Social Distancing in order to Handle Corona Virus Disease 2019 (COVID-19).

8. Governor of DKI Jakarta. (2020). DKI Jakarta Governor Regulation No.33 Year 2020 regarding Implementation of Large Scale Social Distancing in order to Handle Corona Virus Disease 2019 (COVID-19) in DKI Jakarta Province.

9. Independent Commission on Multilateralism. (2017). "Global Pandemics and Global Public Health," New York: International Peace Institute, available from https:/www.ipinst.org/wpcontent/uploads/2017/10/Global-Pandemics-andGlobal-Public-Health1.pdf accessed on 15 April 2020.

10. Kapp, Marshall (coordinator). (2019). Pandemic Influenza Benchguide: Legal Issues Concerning Quarantine and Isolation $3^{\text {rd }}$ ed. Florida: Florida Office of the State Court Administrator.

11. Lai, A. Y. and S. L. Tan (2012), 'Impact of Disasters and Disasters Risk Management in Singapore: A Case Study of Singapore's Experience in Fighting the SARS Epidemic', in Sawada, Y. and S. Oum (eds.), Economic and Welfare Impacts of Disasters in East Asia and Policy Responses. ERIA Research Project Report 2011-8, Jakarta: ERIA. pp.463-501.

12. LePan, Nicholas. (2020). A visual history of pandemics." Available from 
https:/www.weforum.org/agenda/2020/03/avisual-history-of-pandemics accessed on 15 April 2020.

13. Mahtani, Kamal R., Carl Heneghan, and Jeffrey K. Aronson. (2020). "What is the evidence for social distancing during global pandemics? A rapid summary of current knowledge." The Centre for Evidence-Based Medicine, available from https://www.cebm.net/covid-19/what-is-theevidence-for-social-distancing-during-globalpandemics/ accessed on 15 April 2020.

14. Minister of Health Republic of Indonesia. (2009). Minister of Health Decree No.300/MENKES/SK/IV/2009 regarding Guidance for the Influenza Pandemic Epicenter Countermeasures.

15. Minister of Health Republic of Indonesia. (2020). Minister of Health Regulation No.9 Year 2020 regarding Guidance for Large Scale Social Distancing in order to Accelerate the Handling of Corona Virus Disease (COVID-19).

16. Minister of Health Republic of Indonesia. (2020). Minister of Health Decree No.HK.01.07/MENKES/239/2020 regarding Determination of Large Scale Social Distancing in DKI Jakarta Province Area in order to Accelerate the Handling of Corona Virus Disease 2019.

17. Morens, David M., Gregory K. Folkers, and Anthony S. Fauci. (2009). "What Is a Pandemic?" The Journal of Infectious Diseases;200:1018-21.

18. Parmet, Wendy E. and Michael S. Sinha. (2020). "Covid-19 - The Law and Limits of Quarantine." The New England Journal Of Medicine; (28):1-3, available from https://www.nejm.org/doi/pdf/10.1056/NEJMp20 04211 accessed on 15 April 2020.

19. President of Republic of Indonesia. (2020) President Decree No.11 Year 2020 regarding the Determination of Public Health Emergency Corona Virus Disease.

20. Qiu, W.; Rutherford, S.; Mao A. and C. Chu C. (2016-2017). "The Pandemic and its Impacts." Health, Culture and Society;9-10:3-11 | DOI 10.5195/hcs.2017.221

21. Rashid, Harunor \& Ridda, Iman \& King, Catherine \& Begun, Matt \& Tekin, Hatice \& Wood, James \& Booy, Robert. (2014). "Evidence compendium and advice on social distancing and other related measures for response to an influenza pandemic." Paediatric Respiratory Reviews. 16. 10.1016/j.prrv.2014.01.003.

22. Republic of Indonesia. (1984). Law No.4 Year 1984 regarding Infectious Disease Epidemic. State Gazette Year 1984 No.20, Supplement No.3273.

23. Republic of Indonesia. (2007). Law No.24 Year 2007 regarding Disaster Management. State
Gazette Year 2007 No.66, Supplement No.4723.

24. Republic of Indonesia. (2014). Law No.23 Year 2014 regarding Local Government. State Gazette Year 2914 No.244, Supplement No.5587.

25. Republic of Indonesia. (2018). Republic of Indonesia Law No.6 Year 2018 regarding Health Quarantine. State Gazette Year 2018 No.128, Supplement No.6236.

26. Richards, Edward P., Katherine C. Rathbun, Corina Sole Brito and Andrea Luna. (2006). The Role of Law Enforcement in Public Health Emergencies; Special Consideration for an AllHazards Approach. Washington DC: US Dept. of Justice.

27. Social Science in Humanitarian Action. (2020). Available https://www.socialscienceinaction.org/wpcontent/uploads/2020/03/SSHAP-Brief.OnlineInformation.COVID-19.pdf accessed on 18 April 2020.

28. Tognotti, Eugenia. (2013). Lessons from the History of Quarantine, from Plague to Influenza A. Emerging infectious diseases;19:254-9. 10.3201/eid1902.120312.

29. Widjaja, Gunawan. (2020a). "Covid-19: Regulasi Setengah Hati." available from https://www.hukumonline.com/berita/baca/lt5e 8 b fd9397a9b/covid-19--regulasi-setengah-hati-oleh-gunawan-widjaja/ accessed on 17 April 2020

30. Widjaja, Gunawan. (2020b). "Bagaimana Melaksanakan Pembatasan Skala Berskala Besar."

31. Wilder-Smith, Annelies \& Freedman, D. (2020). Isolation, quarantine, social distancing and community containment: pivotal role for old-style public health measures in the novel coronavirus (2019-nCoV) outbreak. Journal of travel medicine. 27. 10.1093/jtm/taaa020.

32. World Health Organization. (2005). WHO Checklist for Influenza Epidemic Preparedness Planning. Switzerland: WHO.

33. World Health Organization. (2010). A WHO Guidance Document; Pandemic Influenza Preparedness and Response. France: WHO. 